\title{
What causes organizations to fail? A review of literature to inform future food sector (management) research
}

by Higashi, S.Y., Morales de Queiroz Caleman, S., de Aguiar, L.K. and Manning, L.

Copyright, publisher and additional Information: This is the author accepted manuscript. The final published version (version of record) is available online via Elsevier.

This version is made available under the CC-BY-ND-NC licence:

https://creativecommons.org/licenses/by-nc-nd/4.0/legalcode

Please refer to any applicable terms of use of the publisher

DOI: https://doi.org/10.1016/j.tifs.2020.05.011

$\mathbf{H}$

Harper Adams University

Higashi, S.Y., Morales de Queiroz Caleman, S., de Aguiar, L.K. and Manning, L. 2020. What causes organizations to fail? A review of literature to inform future food sector (management) research. Trends in Food \& Science Technology. 


\section{What causes organisations to fail? A systematic review of the literature to inform future management research.}

Susan Yuko Higashi, ${ }^{1}$ Silvia Morales de Queiroz Caleman ${ }^{1}$ Luis Kluwe de Aguiar ${ }^{2}$ and Louise Manning ${ }^{3}$

${ }^{1}$ UFMS - Universidade Federal de Mato Grosso do Sul, Brazil

${ }^{2}$ Harper Adams University, Newport, Shropshire, UK TF10 8NB

${ }^{3}$ Royal Agricultural University, Stroud Road, Cirencester, Gloucestershire, UK GL7 6JS

(corresponding author)

\section{Abstract}

Background: Organizational failure in food markets is a potential threat to food security.

Thus, a greater understanding of the factors that influence organizational failure and reduce supply chain resilience is essential to underpin agile and dynamic food supply chains.

Scope and Approach: The aim of this paper is to contribute to the understanding of system level factors that influence organizational failure in food supply chains in order to conceptualize the horizontal and vertical interaction of such factors at the three levels described: the microsystem, the mesosystem and the macrosystem level. A systematic review incorporated articles from the fields of management, business and economics research. Whilst 616 articles were initially identified, only 41 of these were within the established inclusion criteria and reviewed. A model of organizational failure, determined here as "The House of Cards Model", is developed, that can then be empirically tested in further research.

Key findings and conclusions: A hierarchy was developed to contextualize the factors deemed to be of influence. The macro (external environment) level includes criteria such as economic conditions, formal institutions, government policies, competitors and rumors. The factors addressed in the meso (organizational) level include organization age and size, location,

\footnotetext{
${ }^{1}$ This study was in part supported by the Coordenação de Aperfeiçoamento de Pessoal de Nível Superior - Brasil (CAPES) - Finance Code 001.
} 
property structure, client, supplier and shareholder relationships, financial resources, physical

resources, human resources and succession process. At the micro (individual) level the managers' skill, characteristics, actions and mindset are of influence. This paper contributes to advancing the debate and underpins further empirical research on organizational failure in food supply chains.

Key words: organizational; failure; meso; micro; macro; factors

\section{Highlights}

- Food supply chain and organizational resilience underpins global food security.

- Factors leading to organisational failure operate at micro, meso and macro levels.

- Failure factors can impact individually or in a combined effect.

\section{Introduction}

Developing a theoretical literature on studying organizations that succeed is of interest but to gain a greater understanding of the reasons that organizations fail gives a valuable insight into aspects of organizational performance (Mellahi \& Wilkinson, 2010) and also offers the research opportunity to learn "what not to do" (Kim, 2007). External international and national economic conditions influence organizational failure i.e. a period of economic slowdown, (zero growth or even by recession) tends to lead to a low rate of investment and a decrease in consumption levels, leading to aggravating external conditions for the company (Box, 2008). Further, during periods of economic crisis organizations cannot attract new investors and/or consumers, therefore, paralyzing their growth rate (Gok, Deshpande, S., Deshpande, A. P., \& Hunter, 2012; Laitinen \& Lukason, 2014; Gémar, Moniche \& Morales, 2016; Nummela, Saarenketo \& Loane, 2016; Petković, Jäger \& Sašić, 2016; Pardo \& Alfonso, 2017). Contracting macro-economies tend to drive an increase in unemployment rate, further exacerbating the pressure on consumers, slowing consumption and accelerating organizational 
51 failure (Box, 2008; Buehler, Kaiser \& Jaeger, 2012). Therefore, to decrease the risk of failure, organizations should focus on food markets where there are increasing or diversified consumer populations (Wollebaek, 2009). This is an argument often used for an organization to develop a strategy of global positioning in multiple markets to reduce the risk of a downturn in one particular national or regional market. Higher interest rates, if they cannot be serviced by increased revenue and/or profitability, can increase organizational debt and as access to financing and refinancing becomes more expensive, the potential for organizational failure also increases (Box, 2008; Priego, Lizano \& Madrid, 2014; Petković, Jäger \& Sašić, 2016).

Furthermore, the tax rate paid by the organization can have a mixed influence. High taxes increase the risk of failure by increasing business costs (Buehler, Kaiser \& Jaeger, 2012; Petković, Jäger \& Sašić, 2016). Conversely, García-Ramos, Gonzalez-Alvarez and Nieto (2017) assert that higher taxes reduce organizational failures, as these taxes are a barrier to market entry for new competitors and, countries with higher tax rates enforce practices that lead to managers being more careful and disciplined in relation to their accountability to the government. Government intervention also affects the rate of companies' failure. In a region or locality where there is high public investment this creates a favorable environment for companies to work in, thus, a smaller failure rate is predicted (Arasti, 2011; Buehler, Kaiser \& Jaeger, 2012). However, government decisions to enable a more liberal economy can increase the rate of organizational failure. This results in new competitors entering a regional/local market, who may introduce new and innovative technologies that decrease production costs, and as a consequence lower prices intensifying competition (Safley, 2009; Amankwah-Amoah \& Debrah, 2010; Madrid-Guijarro, García-Pérez-de-Lema \& Van Auken, 2011; Gok, Deshpande, S., Deshpande, A. P., \& Hunter, 2012; Pardo \& Alfonso, 2017). Fake rumors relating to the organization circulated by others are difficult to reverse, and negative consumer 
perceptions or experience associated with faulty or contaminated products will affect organizational survival (Amankwah-Amoah, Antwi-Agyei \& Zhang, 2018).

Institutions, and in particular formal institutions such as the legal system, supply chain assurance, certification and constitutional instruments, play a role to play, because depending on their purpose and how they were constituted, institutional factors can impact both positively or negatively on organizational failure (Oertel, Thommes \& Walgenbach, 2016). Organizations may not always have the legal knowledge required to navigate formulated laws that are very technical, and do not act in their favor (Yonk, Harris, Martin \& Anderson, 2017). More complex and bureaucratic legislation gives rise to high costs for companies, potentially judicial inefficiency and reduces organizational agility as it can take a long time to open or close a business. Further, these factors lead to a high consumption of organizational and institutional resources on ensuring legal compliance, often reducing productivity levels as a result so increasing the risk of organizational failure (Petković, Jäger \& Sašić, 2016; García-Ramos, Gonzalez-Alvarez \& Nieto, 2017).

Regulation of factors including location and construction of new premises, access to new technologies and materials all increase organizational costs (Yonk, Harris, Martin \& Anderson, 2017); and potentially organizational resilience, although targeted institutional governance also has a positive effect in reducing organizational failure (Bordonaba-Juste, Lucia-Palacios \& Polo-Redondo, 2011). The existence of quality certification systems such as ISO 9000, is associated with an organization's positive financial performance (Madrid-Guijarro, A., GarcíaPérez-de-Lema, D., \& Van Auken, 2011), probably because the organization has better management systems, and consequently, its internal processes focus on meeting customer requirements and continuous improvement. Indeed, the development of third-party certification schemes as a way to drive resilience and risk reduction is well established in food supply chains (Manning, 2018; Manning, Luning and Wallace, 2019). Organizational 
recovery laws underpin organizational survival as weaker recovery laws increase the risk of organizational failure (White, 2016). This type of institutional support can be both public (state derived) and private (non-state and market derived).

The investigation of organizational failure at the food supply chain level is limited: considering risk (Olson \& Wu, 2010); halal supply chains (Ab Talib, Abdul Hamid \& Zulfakar, 2015); supermarket supply chains (Wegner \& Padula, 2012) and in some research through proposing an integrative model (Mellahi \& Wilkinson, 2004; Amankwah-Amoah et al. 2016). However, in developing an integrated model that includes all the factors that play a role in influencing organizational failure in food supply chains, a systems level approach needs to be considered and that is the original element of the research described here. The hierarchical classification of factors of influence in organizational failure that is used in this paper is based on the structural analysis approach of socio-ecological theory as proposed by Bronfenbrenner (1986). There are three levels of analysis: the macrosystem (the broader social, political, institutional and economic conditions of the external environment), the mesosystem (the internal organizational environment) and the microsystem (the individual and their immediate environment).

Drawing upon a comparative analysis perspective, this paper, after exclusion criteria are applied, systematically reviews 41 published articles in peer-reviewed journals from 2008 to 2018. We need to add here what the discipline source of the papers was to address comment 2 The aim of this paper is to contribute to the understanding of system level factors that may influence organizational failure in food supply chains pre sale to the consumer in order to conceptualize the horizontal and vertical interaction of such factors. This paper contributes to advancing the debate on organizational failure in food supply chains by firstly drawing together and synthesizing more general literature on organisational failure to then develop a food supply chain related conceptual model which is deduced from the literature. Secondly, the structural, 
cultural and sociological aspects of organizational failure are considered in order to develop a set of propositions that can be tested in further empirical research on organizational failure in food supply chains.

Machi and Mcevoy (2009) to develop a written academic reflection that provides a logical argument based on a "comprehensive understanding of the current state of knowledge" about in more detail:

(i) select the topic-organizational failure is the topic chosen in order to specify and

\section{Approach}

In undertaking this research we used the six-step systematic process as described in the given topic, in this case, organizational failure. The six steps employed are now addressed frame the review;

(ii) search the literature - Web of Science was used for this purpose. The following keywords were used by checking for the presence in the title or abstract: (business failure) OR (organizational failure) OR (organizational death) OR (organizational mortality) OR (organizational output) OR (organizational decline). The focus period was narrowed down to the years between 2008 and 2018, so as to include the most up-to-date research publications. The journal inclusion criteria were disciplines of Management, Business and Economics. The inclusion criteria were that: (a) the article addressed organizational failures, and the main objective of study was improving understanding of organizational failure; and (b) the exclusion criteria were based on: the identification of article duplicates resulting from the use of different search terms or the article did not add to the argument on organizational failure. The search identified 616 articles with duplicates $(n=20)$ excluded and then further exclusions $(n=451)$ based on the criteria outlined above with regard to the title and abstract. The remaining articles 
$(n=145)$ were read in full, and the exclusion criteria was applied again. That resulted in further exclusions $(n=104)$. leaving the final articles $(n=41)$ suitable for further analysis (see Figure 1 and Table 1).

(iii) develop the argument - the argument herein was based on the aforementioned tri-level system analaysis of macro, meso and micro factors of influence;

(iv) Survey the literature - the literature was then read and evidence synthesized see model.

\subsection{Macro analytical level:}

171 To analyze the variables at the macro analytical level, nine factors were highlighted from wider business literature that underpin organizational success or alternatively may drive 
within the introduction of this paper. The factors can be categorized as either economic factors: financial or economic crises, interest rates, taxation systems, and the degree of liberalization of the economy; or secondly social factors in terms of structural or institutional factors, government policies and the degree of public investment. Thirdly, market factors in terms of competitive factors and the potential for rumors about the company whether real or fictitious (see Mellahi \& Wilkinson, 2004).

\subsection{Meso analytical level:}

The meso analytical level is the context of the factors that influence organizational failure at the organizational level. Strategic profile is crucial i.e. the internal resources, and the strategic relationships and networks with clients, suppliers and competitors should drive a viable and resilient business (Mellagi \& Wilkinson, 2004). Category management approaches in food supply chains over recent years have driven these strategic relationships and value creation and, as a result of recent advances digital technology, are likely to develop further (Mantrala \& Kamran-Disfani, 2018; Chkoniya \& Mateus 2019). To ensure its long-time survival, the organization should have a good relationship with its shareholders. If this relationship is weak, shareholders could believe the organization is not capable of generating value in the long term and, therefore, the shareholders will reduce the amount of equity they have invested in the organization. Thus, enterprises with a poor relationship with their shareholders tend to have a higher likelihood of organizational failure (Priego, Lizano \& Madrid, 2014). Relationships with other direct supply chain actors such as suppliers and customers are equally important. The organization's relationship with suppliers is crucial to organizational survival, because problems associated with inputs or contractual issues can be significant in increasing organizational vulnerability (Pardo \& Alfonso, 2017). For example, suppliers increasing the price of the raw materials when this cannot be passed on to the customer, reduces operating margins (Gok, Deshpande, S., Deshpande, A.P. \& Hunter, 2012; 

factor, because if its clients have greater bargaining power, the organization cannot control the price of the goods and services it sells and thus its operating margin, increasing vulnerability and directly affecting its chances of survival (Madrid-Guijarro, García-Pérez-de-Lema \& Van Auken, 2011). Location choice impacts on network relationships and can benefit, or alternatively prejudice, organizational survival. When the location is well-chosen, meso-level externalities generate benefits such as better access to human capital and financial resources (Williams, 2016). Further, if the business location is composed of organizations from similar or synergistic sectors, this can generate knowledge transfer and exchange between these organizations for mutual benefit (Nilsson, 2016). When an organization is located near universities or research centers, it can benefit from access to new innovations, technologies and information, ensuring long-term competitiveness (Nilsson, 2016; Williams, 2016; MatéSánchez-Val, López-Hernandez \& Fuentes, 2018). An example of the benefits of food business clusters associated with a university can be found in Food Valley at Wageningen which links food business with research centres of excellence (Omta W. \& Fortuin, 2013). However, the probability of some organizations failing is greater if the business is surrounded by other organizations that have also failed (Maté-Sánchez-Val, López-Hernandez \& Fuentes, 2018) and if the business is near to non-cooperative competitors (Safley, 2009; Nilsson, 2016).

The organization's age is a variable that many sources identify as being important to explain the risk of organizational failure. Younger organizations tend to present a higher failure rate, while conversely older organizations present a higher survival rate (Box, 2008; MadridVivel-Bua, Lado-Sestayo \& Otero-González, 2016). This occurs, because usually, older businesses have already developed the expertise, competence and experiences that ensure resilience in crises and difficult times (Esteve-Pérez \& Mañez-Castillejo, 2008; Wollebaek, 

Palacios \& Flight, 2014). An organization's size is said in the literature to be a factor of influence. The likelihood of organizational failure is greater in smaller organizations as they lack economic scale and scope (Box, 2008; Esteve-Pérez \& Mañez-Castillejo, 2008; Wollebaek, 2009; Bordonaba-Juste, Lucia-Palacios \& Polo-Redondo, 2011; Fackler, Schnabel \& Wagner, 2013; Kalnins, 2016; Vivel-Bua, Lado-Sestayo \& Otero-González, 2016). Further larger organizations may hold greater material stock quantities that would guarantee the continuation of production even under the impact of severe external meso-level pressure (Williams, 2016). The use of organizational size as a factor to explain organizational failure proves to be an interesting criterion. The classification of what is a small, medium or large organization distinctively varies in the literature between different research studies. Indeed, whilst organizational size is articulated as being important to explain organizational failure, sources fail to describe in their research what is classed as a small, medium or large organization. In Europe, the categorization of organizational size uses criteria such as the number of employees, turnover or size of balance sheet (European Commission, 2016). Bordonaba-Juste, Lucia-Palacios and Polo-Redondo (2011) and Fackler, Schnabel and VivelBua, Lado-Sestayo and Otero-González, 2016 did not quantify the size effect. Others defined business size by the number of employees or turnover (Box, 2008; Esteve-Pérez \& MañezCastillejo, 2008; Fackler, Schnabel \& Wagner, 2013; Williams, 2016). is a cited factor. Monetary assets are the key resources used by organizations to manage and "smooth out" moments of financial or production difficulty (Williams, 2016; Alaka et al. 2017). High operating margin, higher retained earnings, liquidity and cashflow are all 247 beneficial for organizational survival (Esteve-Pérez \& Mañez-Castillejo, 2008; Vivel-Bua, 
base and having better financial control (Baidoun, Lussier, Burbar \& Awashra, 2018). This can prove to be a challenge to achieve in practice in often low profit- margin food supply chains

251 (Callado \& Jack, 2017).

As well as financial resources, an organization's physical resources, depending on their innate characteristics, can aid organizational survival. In competitive environments, companies with higher technological levels than others experience better survival rates and are less affected by business environment changes, generally because they have a higher added value and thus a greater product margins (Madrid-Guijarro, García-Pérez-de-Lema \& Van Auken, 2011). The introduction of innovations such as Blockchain technology to reduce transaction costs and improve transparency is a case in point (Shermin, 2017; Kamilaris, Fonts \& Prenafeta-Boldú, 2019; Schmidt \& Wagner, 2019). Therefore, to ensure survival, manufacturing organizations require an adequate level of physical resources (stock) to ensure the development of specific products and a higher production rate to dilute the fixed costs of production such as wages, rent and so forth (Esteve-Pérez \& Mañez-Castillejo, 2008; Gutierrez, Meleddu \& Piga, 2017).

The third organizational resource type is human resources, fundamental for the organization to differentiate itself from its competitors. Investment in employee training to ensure product and/or service delivery in line with contractual obligations is essential to generate improved profitability and value creation (Safley, 2009; Van Scheers, 2011; Priego, Lizano \& Madrid, 2014; Petković, Jäger \& Sašić, 2016; Pardo \& Alfonso, 2017; Baidoun, Lussier, Burbar \& Awashra, 2018). The common problem that family businesses face is poor succession management leading to organizational failure and emotional barriers around being replaced or delegating decision-making (Santiago, 2015). Therefore, mindset has a crucial role at the micro level of the organization. Weak governance and a reticence to let non-family members have positions of power means some enterprises are simply sold or closed (Santiago, 
2015). The way that a company organizes its executive board, as well as its own organizational structure can aid in the understanding why some organizations fail, while others succeed. Successful companies have a small turnover of board members, and organize their executive board to have local directors with a knowledge base with local specificity (Wilson, Wright \& Altanlar, 2014). Wilson, Wright and Altanlar (2014) also note that due to their characteristics of conflict avoidance and creating strategies that add value to the organization, the number of women present on the board has an impact too. Organizational success is associated with governance that includes external directors (Baidoun, Lussier, Burbar \& Awashra, 2018), perhaps for the additional skillsets and experience that they provide. When a family member is involved in management and actively participates in the executive board, there is less risk of organizational failure. Indeed, in times of financial hardship, a family member is more willing to contribute from their own resources to help the organization survive (Revilla, Pérez-Luño \& Nieto, 2016). A further meso-level factor that contribute to vulnerability in periods of external crisis include the hierarchical nature of the organization, the level of formalization of systems, protocols and procedures, as these will influence an organization's ability, if needed, to restructure successfully (Wollebaek, 2009). The micro analytical level is now considered.

\subsection{Micro analytical level}

The micro level of the model considers the importance of the individual whether that is the managers and/or employees and their responsibility to ensure the organization survives rather than fails. Managers are the principal micro level factor that causes organizations to fail, because they are responsible for key decision-making within the organization and operationalizing and implementing strategic organizational plans (Arasti, 2011; Laitinen \& Lukason, 2014; Gémar, Moniche, \& Morales, 2016; Purves, Niblock \& Sloan, 2016). Aspects such as managers' overconfidence, lack of qualification, little or no experience in the business area, lack of organizational skills and a lack of focus on strategy all play a part in reducing the 
efficiency of the manager within an organization. This situation will also reduce the potential to meet competition and/or meet client needs so the client base can become stagnant and this increases the likelihood of business failure (Almandoz \& Tilcsik, 2016; Nummela, Saarenketo \& Loane, 2016; Alaka et al. 2017; Pardo \& Alfonso, 2017; Baidoun, Lussier, Burbar \& Awashra, 2018). Manager's experience is important, as a more experienced manager can adopt skills and implement routines when they face similar problems to those they have experienced before. In addition, they can have access to an alternative network with new external resources new clients and they have better knowledge of the market (Wilson, Wright, \& Altanlar, 2014). The risk associated with managerial decision-making is also a factor. However, there are multiple factors of influence here from managers who are afraid of failure or do not like to take risk, and they present less probability of organizational failure compared with managers that like to take more risky decisions (García-Ramos, Gonzalez-Alvarez \& Nieto, 2017). However, as previously outlined, managers who fail to take advantage of new opportunities can in turn drive the business into a stagnant market, which in itself can lead to organizational failure, so the balance of influence of managerial decision-making is important. As outlined previously mindset is a key factor in organizational success or failure. Cognitive entrenchment, i.e. a rigidity in mindset means the probability of recognizing, interpreting and integrating new information is low, and when faced with external influences, these managers have a certain resistance to changing their perspectives and thus behavior (Almandoz \& Tilcsik, 2016). Hollow (2014) studied strategic inertia and managers' resistance to change in alignment with the organization's strategic direction and concluded that such negative behavior was fundamental to why organizations fail. Managers when faced with external change who do not want to make operational or strategic adjustments believe that the existing strategy is more adequate, despite the evidence before them. Therefore, having a rigid mindset in the face of change becomes a crucial factor in organizational failure (Amankwah-Amoah \& Debrah, 2010; 
Santiago, 2015; Oertel, Thommes \& Walgenbach, 2016). This literature suggests managers should develop a mindset open to innovation, problem-solving skills and their leadership style should be more authoritarian in difficult times, while, in times of stable consumption and turnover these managers should have a leadership style that is more democratic and charismatic (Dubrovski, 2009). Despite the importance that managers have in contributing to organizational survival, or alternatively organizational failure, they often do not see themselves as a chiefly responsible, in some literature attributing all the blame for failure on external (macro-level) variables (Arasti, 2011; Gok, Deshpande, S., Deshpande, A.P. \& Hunter, 2012).

\section{Discussion}

Whilst this systematic literature review has highlighted multiple factors of influence on organizational failure, there is no clear lead on their magnitude or level of importance or indeed the impact of their interplay with each other, particularly in food supply chains. Figure 2 draws together and categorizes the factors identified within the literature examined said to have a potential for organizational survival. Further, a series of factors are deduced from the wider literature can be empirically tested in future research looking specifically at organizational failure in the food supply chain.

This research led to the development of a conceptual model termed "The House of Cards Model" of organizational failure (Figure 3) to reflect the hierarchical level of influence of these variables, their positive or negative influence and their interplay with each other. Other models of organizational failure have been developed and three are considered here to compare and contrast with "The House of Cards Model." Mellahi \& Wilkinson (2004) set a context of external environment and organizational characteristics such as age and size of organization. Their integrative model considers environmental factors at the macro level that are outside the 
control of the organization e.g. demographic, technological, regulatory and economic changes and also ecological factors that encompass both macro (density, industry life cycle) and meso (age, size) characteristics. The meso/ micro factors associated with the manager and management are split into two types: organizational factors (management) and psychological factors (manager). They concur with the findings of this paper that there is a symbiosis between external and internal factors that influence organizational failure and that macro factors can have an independent influence on failure (the bottom tier of the House of Cards model). Amankwah-Amoah (2016) also considers that organizational failure can be represented by an integrative process model that differentiates between external (macro) factors and firm level factors and that these work together to drive stages of organizational decline that lead to organizational failure. They distinguish between positive and negative "jolts" which can influence organizational stability. Their model is not nuanced in terms of differentiating organizational stability and which jolts can have significant effect. The bottom tier of "The House of Cards" model shows more clearly how vulnerable the organization is to external environmental jolts that are often outside the manager's control. Amankwah-Amoah (2016) also highlights the value of resources to add buffer capacity to the organization (the middle tier of the House of Cards model). A strong middle tier can add organizational resilience and stability compared to other organizations in the same field that may have lower cash reserves, lower physical and human resource levels and weaker supply chain and consumer relationships. Crutzen \& Callie (2008) also develop an integrative model for organizational failure that agin highlights organizational characteristics such as age or size of organization. Again, this model considers the external environment (the macro level) and the potential for misalignment. The inner layer of the model then considers the meso layer in terms of interaction with stakeholders and relationships, resource deployment and management policies. The macro level is not considered explicitly. The Crutzen \& Callie model also considers the development of early 
warning signals based on inherent weaknesses at the meso or macro level. The House of Cards

Model described here also details twenty-four factors around which an early warning metricsbased system could be developed. Further, the "House of Cards Model" illustrates that for an organization to be resilient; it should consider and reduce the risk of negative influences at the macro, meso and micro analytical level. The three levels are interdependent, so, any fragility in one hierarchical layer can cause stress in another and if the weakness generated is large enough within this model at any level, it can trigger organizational failure.

The macro analytical level is composed of variables external to the organization, and these are common to all businesses, but of particular concern in low margin food supply chains less resilient to market shocks or long-term squeezes that stifle profitability and innovation. Organizations do not have the control over such variables, so if the organization wants to ensure its long-term survival, it must adapt in the micro and meso level to reduce vulnerability to the factors of influence at the macro level. If the organization cannot mitigate or offset the risks associated with external environment, it will fail because the entire 'House of Cards' will collapse as the foundations have been weakened irretrievably irrespective of how strong the other layers are.

By focusing on its internal organizational resources - at the meso analytical level - the organization can seek to adapt to influencers. Therefore, the strategic and operational management of these economic, market and social resources must be effective to ensure organization survival. This is especially important in terms of developing resilient and strong organizational relationships with shareholders, suppliers and customers. Effective management of internal organizational resources will depend on the managers (micro analytical level), who are responsible for decision-making and the strategic development of the organization. Therefore, the managers' characteristics, abilities, mindset and actions are fundamental to ensure organization survival. If the management of the organization is weak, its survival is 
threatened. The "House of Cards" model is intentionally developed as a system based rather than a linear model. A linear model implies that if the organization has some fragility in one variable, this can trigger a chain reaction across the business, a form of "domino-effect", and therefore, dependent on the size of the impact and the level of the organization's adaptive capacity then organizational failure may automatically occur. However, in the model presented here if the adaptive capacity is sufficient within the organization, it can build in resilience to market shocks and squeezes. Therefore, the model shows that ensuring organization survival is complex and requires a system based multi-level approach.

\section{Conclusion}

The systematic literature review on the factors influencing organizational failure has identified the main variables that can lead an organization to fail. Organizational failure can be both positively and negatively influenced by such factors, which operate at three system levels: macro, meso and micro. Based on the analysis of these variables, it was possible to develop "The House of Cards Model” of organizational failure. Such a model illustrates and can help individuals to understand the complex and interconnecting reasons that can lead to organizational failure in food supply chains and provides factors that can be integrated into a metrics based early warning system. The three analytical levels presented in the model are interdependent, i.e., a change in one level should affect the other levels. Consequently, ensuring the long-term success of an organization is a complex task and requires a system-based approach. Further, if the organization wants to ensure its long-term survival, it will need to develop resilience capabilities and agile adaptive capacity at all three levels. However, if there is a major impact at the macro level this can lead to organizational failure in some businesses, even if the systems at the micro and meso levels are strong. Therefore, it is important to the field of organizational food studies literature to identify the variables of interest and the connected development of organizational adaptive capacity. The main limitation of this 
research is that the propositions have not been yet tested, making it difficult to demonstrate the veracity and influence of each one. This empirical work has however been informed by the literature review and is currently being undertaken by the research team. Empirical research is required to verify both how the variables individually and collectively influence organizational failure and also how mitigation measures can be implemented.

This study has implications for all managers, but particularly those who create cognitive distance between themselves and the factors that influence organizational failure. Creating cognitive distance can allow managers or executives to seek to exempt themselves from any responsibility when an organization is going through a difficult period. Furthermore, this study confirms that the managers' lack of experience, skills and knowledge and even overconfidence can all contribute to organizational failure. Therefore, managers should be aware of their particular role in ensuring organizational survival and growth and awareness of the multiple factors of influence is a major step towards developing resilient businesses.

\section{References}

Ab Talib, M. S., Abdul Hamid, A. B., \& Zulfakar, M. H. (2015). Halal supply chain critical success factors: a literature review. Journal of Islamic Marketing, 6(1), 44-71.

Alaka, H. A., Oyedele, L. O., Owolabi, H. A., Oyedele, A. A., Akinade, O. O., Bilal, M., \& Ajayi, S. O. (2017). Critical factors for insolvency prediction: towards a theoretical model for the construction industry. International Journal of Construction Management, 17(1), 25-49.

Almandoz, J., \& Tilcsik, A. (2016). When experts become liabilities: Domain experts on boards and organizational failure. Academy of Management Journal, 59(4), 1124-1149.

Amankwah-Amoah, J., Antwi-Agyei, I., \& Zhang, H. (2018). Integrating the dark side of competition into explanations of business failures: Evidence from a developing economy. European Management Review, 15(1), 97-109.

Amankwah-Amoah, J., \& Debrah, Y. A. (2010). The protracted collapse of Ghana Airways: Lessons in organizational failure. Group \& Organization Management, 35(5), 636-665.

Amankwah-Amoah, J. (2016). An integrative process model of organisational failure. Journal of Business Research, 69(9), 3388-3397.

Arasti, Z. (2011). An empirical study on the causes of business failure in Iranian context. African journal of business management, 5(17), 7488-7498. 
Baidoun, S. D., Lussier, R. N., Burbar, M., \& Awashra, S. (2018). Prediction model of business success or failure for Palestinian small enterprises in the West Bank. Journal of Entrepreneurship in Emerging Economies, 10(1), 60-80.

Bordonaba-Juste, V., Lucia-Palacios, L., \& Polo-Redondo, Y. (2011). An analysis of franchisor failure risk: evidence from Spain. Journal of Business \& Industrial Marketing, 26(6), 407-420.

Bronfenbrenner, U. (1986). Ecology of the family as a context for human development: Research perspectives. Developmental psychology, 22(6), 723

Buehler, S., Kaiser, C., \& Jaeger, F. (2012). The geographic determinants of bankruptcy: evidence from Switzerland. Small Business Economics, 39(1), 231-251.

Box, M. (2008). The death of firms: exploring the effects of environment and birth cohort on firm survival in Sweden. Small Business Economics 31, 379-393

Callado, A. A. C., \& Jack, L. (2017). Relations between usage patterns of performance indicators and the role of individual firms in fresh fruit agri-food supply chains. Journal of Applied Accounting Research. 18(3), 375-398

Camillo, A. A., Connolly, D. J., \& Kim, W. G. (2008). Success and failure in Northern California: Critical success factors for independent restaurants. Cornell Hospitality Quarterly, 49(4), 364-380.

Chkoniya, V., \& Mateus, A. (2019). Digital Category Management: How Technology Can Enable the Supplier-Retailer Relationship. In Smart Marketing With the Internet of Things (pp. 139-163). IGI Global.

Ciampi, F. (2015). Corporate governance characteristics and default prediction modelling for small enterprises. An empirical analysis of Italian firms. Journal of Business Research, 68(5), 1012-1025.

Crutzen, N., \& Van Caillie, D. (2008). The business failure process: an integrative model of the literature. Review of Business and Economics, 53(3), 287-316

Dobbs, M. E., Boggs, D. J., Grünhagen, M., Palacios, L. L., \& Flight, R. L. (2014). Time will tell: interaction effects of franchising percentages and age on franchisor mortality rates. International Entrepreneurship and Management Journal, 10(3), 607-621.

Dubrovski, D. (2009). Management mistakes as causes of corporate crises: Managerial implications for countries in transition. Total Quality Management, 20(1), 39-59.

Esteve-Pérez, S., \& Mañez-Castillejo, J. A. (2008). The resource-based theory of the firm and firm survival. Small Business Economics, 30(3), 231-249.

European Comission (2016) User guide to the SME Definition. Available at: https://ec.europa.eu/regional_policy/sources/conferences/stateaid/sme/smedefinitionguide_en.pdf (accessed 22 January 2019)

Fackler, D., Schnabel, C., \& Wagner, J. (2013). Establishment exits in Germany: the role of size and age. Small Business Economics, 41(3), 683-700. 
García-Ramos, C., Gonzalez-Alvarez, N., \& Nieto, M. (2017). Institutional framework and entrepreneurial failure. Journal of Small Business and Enterprise Development, 24(4), 716732 .

Gémar, G., Moniche, L., \& Morales, A. J. (2016). Survival analysis of the Spanish hotel industry. Tourism Management, 54, 428-438.

Gok, K., Deshpande, S., Deshpande, A. P., \& Hunter, G. (2012). Comparing promoter and employee attributions for the causes of firm failure: the case of an Indian petrochemical company. The International Journal of Human Resource Management, 23(12), 2576-2596.

Gutierrez, M. M., Meleddu, M., \& Piga, A. (2017). Food losses, shelf life extension and environmental impact of a packaged cheesecake: A life cycle assessment. Food Research International, 91, 124-132.

Hollow, M. (2014). Strategic inertia, financial fragility and organisational failure: The case of the Birkbeck Bank, 1870-1911. Business History, 56(5), 746-764.

Kamilaris, A., Fonts, A., \& Prenafeta-Boldv́, F. X. (2019). The rise of blockchain technology in agriculture and food supply chains. Trends in Food Science \& Technology, 91, 640-652.

Kalnins, A. (2016). Beyond Manhattan: Localized competition and organizational failure in urban hotel markets throughout the United States, 2000-2014. Strategic Management Journal, 37(11), 2235-2253.

Kim, D. J. (2007). Falls from grace and lessons from failure: Daewoo and Medison. Long Range Planning, 40(4-5), 446-464.

Laitinen, E. K., \& Lukason, O. (2014). Do firm failure processes differ across countries: evidence from Finland and Estonia. Journal of Business Economics and Management, 15(5), 810-832.

Machi, L.A. \& Mcevoy, B.T. (2009), The literature review: six steps to success, Corwin Press, Thousand Oaks, CA.

Madrid-Guijarro, A., García-Pérez-de-Lema, D., \& Van Auken, H. (2011). An analysis of non-financial factors associated with financial distress. Entrepreneurship and Regional Development, 23(3-4), 159-186.

Manning L. Luning, P. \& Wallace, C.A (2019). The Evolution and Cultural Framing of Food Safety Management Systems - Where from and Where next? Comprehensive Reviews in Food Science, 18, 1770-1792

Manning, L. (2018), Triangulation: effective verification of food safety and quality management systems and associated organisational culture World Hospitality and Tourism Themes 10(3), 297-312

Mantrala, M. K., \& Kamran-Disfani, O. (2018). Category management and captains. In Handbook of Research on Retailing. Edward Elgar Publishing. UK

Maté-Sánchez-Val, M., López-Hernandez, F., \& Fuentes, C. C. R. (2018). Geographical factors and business failure: An empirical study from the Madrid metropolitan area. Economic Modelling, 74, 275-283 
Mackie, R. (2012). Bearing 'the burden and heat of the day': The experience of business failure in Douglas \& Grant Ltd. Business History, 54(5), 689-712.

Mellahi, K., \& Wilkinson, A. (2010). Managing and coping with organizational failure: Introduction to the special issue. Group \& Organization Management 35(5), 531-541. DOI: $10.1177 / 1059601110383404$.

Mellahi, K., \& Wilkinson, A. (2004). Organizational failure: a critique of recent research and a proposed integrative framework. International Journal of Management Reviews, 5(1), 2141

Nilsson, P. (2016). The influence of related and unrelated industry diversity on retail firm failure. Journal of Retailing and Consumer Services, 28, 219-227

Nummela, N., Saarenketo, S., \& Loane, S. (2016). The dynamics of failure in international new ventures: A case study of Finnish and Irish software companies. International Small Business Journal, 34(1), 51-69.

Oertel, S., Thommes, K., \& Walgenbach, P. (2016). Organizational failure in the aftermath of radical institutional change. Organization Studies, 37(8), 1067-1087.

Olson, D. L., \& Wu, D. (2011). Risk management models for supply chain: a scenario analysis of outsourcing to China. Supply Chain Management: An International Journal, 16(6), 401-408.

Omta, S. W. F., \& Fortuin, F. T. J. M. (2013). Effectiveness of cluster organizations in facilitating open innovation in regional innovation systems: the case of Food Valley in the Netherlands. In Open Innovation in the Food and Beverage Industry (pp. 174-188). Woodhead Publishing.

Pardo, C., \& Alfonso, W. (2017). Applying "attribution theory" to determine the factors that lead to the failure of entrepreneurial ventures in Colombia. Journal of Small Business and Enterprise Development, 24(3), 562-584.

Petković, S., Jäger, C., \& Sašić, B. (2016). Challenges of small and medium sized companies at early stage of development: insights from Bosnia and Herzegovina. Management: journal of contemporary management issues, 21(2), 45-76.

Priego, A. M., Lizano, M. M., \& Madrid, E. M. (2014). Business failure: incidence of stakeholders' behavior. Academia Revista Latinoamericana de Administración, 27(1), 75-91.

Purves, N., Niblock, S., \& Sloan, K. (2016). Are organizations destined to fail? Management Research Review, 39(1), 62-81.

Revilla, A. J., Pérez-Luño, A., \& Nieto, M. J. (2016). Does family involvement in management reduce the risk of business failure? The moderating role of entrepreneurial orientation. Family Business Review, 29(4), 365-379.

Safley, T. M. (2009). Business failure and civil scandal in early modern Europe. Business History Review, 83(1), 35-60. 
Santiago, A. (2015). Inertia as inhibiting competitiveness in Philippine family businesses. Journal of Family Business Management, 5(2), 257-276.

Schmidt, C. G., \& Wagner, S. M. (2019). Blockchain and supply chain relations: A transaction cost theory perspective. Journal of Purchasing and Supply Management, 25(4), 100552.

Shermin, V. (2017). Disrupting governance with blockchains and smart contracts. Strategic Change, 26(5), 499-509.

Van Scheers, L. (2011). SMEs marketing skills challenges in South Africa. African Journal of Business Management, 5(13), 5048-5056.

Vivel-Bua, M., Lado-Sestayo, R., \& Otero-González, L. (2016). Impact of location on the probability of default in the Spanish lodging industry: A study of MSMEs. Tourism Economics, 22(3), 593-607.

Wegner, D., \& Padula, A. D. (2012). When the cooperation fails: a case study about the failure of an interorganizational network. RAM. Revista de Administração Mackenzie, 13(1), 145-171.

White, M. J. (2016). Small business bankruptcy. Annual Review of Financial Economics, 8, 317-336.

Williams, D. A. (2016). Can neural networks predict business failure? Evidence from small high tech firms in the UK. Journal of Developmental Entrepreneurship, 21(01), 1650005.

Wilson, N., Wright, M., \& Altanlar, A. (2014). The survival of newly-incorporated companies and founding director characteristics. International Small Business Journal, 32(7), 733-758.

Wollebaek, D. (2009). Survival in local voluntary associations. Nonprofit Management and Leadership, 19(3), 267-284.

Yonk, R. M., Harris, K., Martin, R. C., \& Anderson, B. (2017). Exploring the case of The White Moustache: Entrepreneurship and regulatory capture in the milk products industry. Journal of Entrepreneurship and Public Policy, 6(1), 41-59. 
Table 1. Review of Literature Sources

\begin{tabular}{|c|c|c|c|c|}
\hline Journals & Number of articles & Review or research & Journal grade & Percentage of total \\
\hline Academia Revista Latinoamericana de Administración & 1 & & & \\
\hline Academy of Management Journal & 1 & & & \\
\hline African Journal of Business Management & 2 & & & \\
\hline Annual Review of Financial Economics & 1 & & & \\
\hline Business History & 2 & & & \\
\hline Business History Review & 1 & & & \\
\hline Cornell Hospitality Quarterly & 1 & & & \\
\hline Economic Modelling & 1 & & & \\
\hline Entrepreneurship and Regional Development & 1 & & & \\
\hline European Management Review & 1 & & & \\
\hline Family Business Review & 1 & & & \\
\hline Group Organization and Management & 1 & & & \\
\hline International Entrepreneurship and Management Journal & 1 & & & \\
\hline International Journal of Construction Management & 1 & & & \\
\hline International Journal of Human Resource Management & 1 & & & \\
\hline International Small Business Journal & 2 & & & \\
\hline Journal of Business and Industrial Marketing & 1 & & & \\
\hline Journal of Business Economics and Management & 1 & & & \\
\hline Journal of Business Research & 1 & & & \\
\hline Journal of Developmental Entrepreneurship & 1 & & & \\
\hline Journal of Entrepreneurship and Public Policy & 1 & & & \\
\hline Journal of Entrepreneurship in Emerging Economies & 1 & & & \\
\hline Journal of Family Business Management & 1 & & & \\
\hline Journal of Retailing and Consumer Services & 1 & & & \\
\hline Journal of Small Business and Enterprise Development & 2 & & & \\
\hline Management: journal of contemporary issues & 1 & & & \\
\hline Management Research Review & 1 & & & \\
\hline Nonprofit Management and Leadership & 1 & & & \\
\hline Organization Studies & 1 & & & \\
\hline Small Business Economics & 4 & & & \\
\hline Strategic Management Journal & 1 & & & \\
\hline Total Quality Management & 1 & & & \\
\hline Tourism Economics & 1 & & & \\
\hline Tourism Management & 1 & & & \\
\hline Total & 41 & & & \\
\hline
\end{tabular}


625 Table 2. Factors that influence organizational failure derived from the systematic review

\begin{tabular}{|c|c|c|c|c|c|}
\hline $\mathbf{N}^{\mathbf{0}}$ & Author & Title & $\begin{array}{c}\text { Influencing } \\
\text { factors }\end{array}$ & $\begin{array}{c}\text { Level of } \\
\text { influence }\end{array}$ & Impact on failures \\
\hline \multirow{2}{*}{1} & \multirow{2}{*}{$\begin{array}{l}\text { Alaka et al. } \\
2017\end{array}$} & \multirow{2}{*}{$\begin{array}{c}\text { Critical factors for insolvency } \\
\text { prediction: towards a theoretical } \\
\text { model for the construction } \\
\text { industry. } \\
\end{array}$} & $\begin{array}{l}\text { Financial } \\
\text { resources }\end{array}$ & 2 & The lower the profit retained, the greater the probability of organizational failure. \\
\hline & & & Manager & 1 & Managers lacking skills and incapable of strategic planning, increase the probability of organizational failure. \\
\hline 2 & $\begin{array}{l}\text { Almandoz, \& } \\
\text { Tilcsik, (2016) }\end{array}$ & $\begin{array}{c}\text { When experts become liabilities: } \\
\text { domain experts on boards and } \\
\text { organizational failure. }\end{array}$ & Manager & 1 & $\begin{array}{l}\text { The higher proportion of specialist managers in one area within a company, the greater probability of organizational } \\
\text { failure. }\end{array}$ \\
\hline \multirow{2}{*}{3} & \multirow{2}{*}{$\begin{array}{l}\text { Amankwah- } \\
\text { Amoah \& } \\
\text { Debrah (2010) }\end{array}$} & \multirow{2}{*}{$\begin{array}{c}\text { The protracted collapse of Ghana } \\
\text { Airways: lessons in } \\
\text { organizational failure. }\end{array}$} & $\begin{array}{l}\text { Governance } \\
\text { policies }\end{array}$ & 3 & Liberal and globalized economies increase the probability of organizational failure. \\
\hline & & & Manager & 1 & Managers with lack of skills to adapt to external changes increase the probability of organizational failure. \\
\hline 4 & $\begin{array}{c}\text { Amankwah- } \\
\text { Amoah, Antwi- } \\
\text { Agyei \& Zhang, } \\
\text { (2018). } \\
\end{array}$ & $\begin{array}{c}\text { Integrating the dark side of } \\
\text { competition into explanations of } \\
\text { business failure: evidence from a } \\
\text { developing economy. } \\
\end{array}$ & Rumors & 3 & $\begin{array}{l}\text { The greater presence of rumors regarding the existence of contaminated or defective products, the greater probability } \\
\text { of organizational failure. }\end{array}$ \\
\hline \multirow[b]{2}{*}{5} & \multirow[t]{2}{*}{ Arasti (2011) } & \multirow{2}{*}{$\begin{array}{c}\text { An empirical study on the causes } \\
\text { of business failure Iranian } \\
\text { context. }\end{array}$} & Manager & 1 & Presence of managers who lack of the skills to manage the business increase the probability of organizational failure. \\
\hline & & & $\begin{array}{l}\text { Government } \\
\text { policies }\end{array}$ & 3 & Insufficient government policies increase the probability of organizational failure. \\
\hline \multirow{5}{*}{6} & \multirow{5}{*}{$\begin{array}{l}\text { Baidoun, } \\
\text { Lussier, Burbar } \\
\& \text { Awashra, } \\
(2018)\end{array}$} & \multirow{5}{*}{$\begin{array}{l}\text { Prediction model of business } \\
\text { success or failure for Palestinian } \\
\text { small enterprises in the West } \\
\text { Bank. }\end{array}$} & $\begin{array}{l}\text { Financial } \\
\text { resource }\end{array}$ & 2 & $\begin{array}{l}\text { The lower the initial capital of the company, at the time of its foundation, the greater probability of organizational } \\
\text { failure. }\end{array}$ \\
\hline & & & Enterprise age & 2 & The younger the company, the greater probability of organizational failure. \\
\hline & & & Manager & 1 & Inexperienced mangers increase the probability of organizational failure. \\
\hline & & & $\begin{array}{c}\text { Human } \\
\text { resources }\end{array}$ & 2 & Companies whose salespeople have better sales skills, decrease the probability of organizational failure. \\
\hline & & & $\begin{array}{c}\text { Consultancy } \\
\text { support }\end{array}$ & 2 & The presence of external consultancy support decreases the probability of organizational failure. \\
\hline \multirow{3}{*}{7} & \multirow{3}{*}{$\begin{array}{l}\text { Bordonaba-Juste, } \\
\text { Lucia-Palacios \& } \\
\text { Polo-Redondo } \\
\quad(2011)\end{array}$} & \multirow{3}{*}{$\begin{array}{l}\text { An Analysis of franchisor failure } \\
\text { risk: evidence from Spain. }\end{array}$} & Enterprise age & 2 & The younger the organization, the greater probability of organizational failure. \\
\hline & & & Enterprise size & 2 & The more the company grows, and consequently the larger it gets, the lower the probability of organizational failure. \\
\hline & & & Institution & 2 & Quality certification decreases the probability of organizational failure. \\
\hline \multirow{2}{*}{8} & \multirow{2}{*}{$\begin{array}{l}\text { Buehler, Kaiser } \\
\& \text { Jaeger (2012) }\end{array}$} & \multirow{2}{*}{$\begin{array}{l}\text { The geographic determinants of } \\
\text { bankruptcy: evidence from } \\
\text { Switzerland. }\end{array}$} & $\begin{array}{l}\text { Location } \\
\text { (network) }\end{array}$ & 2 & Companies (hotels) being located in tourist areas decreases the probability of organizational failure \\
\hline & & & $\begin{array}{l}\text { Economic } \\
\text { conditions }\end{array}$ & 3 & The higher unemployment is the greater probability of organizational failure. \\
\hline
\end{tabular}




\begin{tabular}{|c|c|c|c|c|c|}
\hline & & & $\begin{array}{l}\text { Government } \\
\text { policies }\end{array}$ & 3 & The lower the level of public investment, the greater the probability of organizational failure. \\
\hline \multirow{3}{*}{9} & \multirow{3}{*}{ Box (2008) } & \multirow{3}{*}{$\begin{array}{l}\text { The death of firms: exploring the } \\
\text { effects of environment and birth } \\
\text { cohort on firm survival in } \\
\text { Sweden. }\end{array}$} & Enterprise age & 2 & The younger the company, the greater the probability of organizational failure. \\
\hline & & & Enterprise size & 2 & The smaller the company, the greater the probability of organizational failure. \\
\hline & & & $\begin{array}{l}\text { Economic } \\
\text { conditions }\end{array}$ & 3 & $\begin{array}{l}\text { An expanding economy decreases the probability of organizational failure. The higher the interest rate, the greater } \\
\text { probability of failure. }\end{array}$ \\
\hline 10 & $\begin{array}{c}\text { Camillo, } \\
\text { Connolly, \& } \\
\text { Kim, (2008). } \\
\end{array}$ & $\begin{array}{l}\text { Success and failure in Northern } \\
\text { California. }\end{array}$ & Manager & 1 & $\begin{array}{l}\text { Inexperienced and unqualified managers increase the probability of organizational failure. Managers that are more } \\
\text { confident and optimistic, the greater probability of organizational failure. }\end{array}$ \\
\hline 11 & Ciampi (2015) & $\begin{array}{c}\text { Corporate governance } \\
\text { characteristics and default } \\
\text { prediction modelling for small } \\
\text { enterprises. An empirical analysis } \\
\text { of Italian firms. } \\
\end{array}$ & $\begin{array}{l}\text { Governance } \\
\text { structurel } \\
\text { institution }\end{array}$ & 2 & $\begin{array}{l}\text { In small companies CEO-duality (the Chief Executive Officer (CEO) and chairman being the same person) decreases } \\
\text { the probability of organizational failure. In small companies, the presence of external directors decreases the } \\
\text { probability of organizational failure if their number is less than } 50 \% \text { of the board members. In, small companies, the } \\
\text { high concentration of companies' shares in the hands of the owners, decreases the probability of organizational failure. }\end{array}$ \\
\hline 12 & $\begin{array}{l}\text { Dobbs, Boggs, } \\
\text { Grünhagen, } \\
\text { Palacios \& Flight } \\
\text { (2014) }\end{array}$ & $\begin{array}{l}\text { Time will tell interaction effects } \\
\text { of franchising percentages and } \\
\text { age on franchisor mortality rates. }\end{array}$ & Enterprise age & 2 & The younger the company, the greater probability of organizational failure. \\
\hline 13 & $\begin{array}{l}\text { Dubrovski } \\
(2009)\end{array}$ & $\begin{array}{l}\text { Management mistakes as causes } \\
\text { of corporate crises: Managerial } \\
\text { implications for countries in } \\
\text { transition. }\end{array}$ & Manager & 1 & $\begin{array}{l}\text { Depending on the macro-economic situation the characteristics of the managers increases the probability of } \\
\text { organizational failure. }\end{array}$ \\
\hline \multirow{3}{*}{14} & \multirow{3}{*}{$\begin{array}{c}\text { Esteve-Pérez \& } \\
\text { Mañez-Castillejo } \\
\text { (2008). }\end{array}$} & \multirow{3}{*}{$\begin{array}{l}\text { The Resource-Based Theory of } \\
\text { firm and firm survival. }\end{array}$} & $\begin{array}{l}\text { Physical } \\
\text { resources }\end{array}$ & 2 & $\begin{array}{l}\text { Companies with assets of specific goods decreases the probability of organizational failure. } \\
\text { Companies with high production and high price-cost margins are less likely to experience organizational failure. }\end{array}$ \\
\hline & & & Enterprise age & 2 & The younger the company, the greater probability of organizational failure. \\
\hline & & & Enterprise size & 2 & The smaller the company, the greater probability of organizational failure. \\
\hline \multirow{2}{*}{15} & \multirow{2}{*}{$\begin{array}{c}\text { Fackler, } \\
\text { Schnabel, \& } \\
\text { Wagner, (2013). }\end{array}$} & \multirow{2}{*}{$\begin{array}{l}\text { Establishment exits in Germany: } \\
\text { the role of size and age. }\end{array}$} & Enterprise size & 2 & The smaller the company, the greater probability of organizational failure. \\
\hline & & & Enterprise age & 2 & The younger the company, the greater probability of organizational failure. \\
\hline \multirow{3}{*}{16} & \multirow{3}{*}{$\begin{array}{l}\text { García-Ramos, } \\
\text { Gonzalez- } \\
\text { Alvarez \& Nieto, } \\
\quad(2017)\end{array}$} & \multirow{3}{*}{$\begin{array}{l}\text { Institutional framework and } \\
\text { entrepreneurial failures. }\end{array}$} & $\begin{array}{l}\text { Governance } \\
\text { structurel } \\
\text { Institution }\end{array}$ & 2 & Complex and/or bureaucratic institutions increase the probability of organizational failure. \\
\hline & & & $\begin{array}{l}\text { Economic } \\
\text { conditions }\end{array}$ & 3 & The higher the taxes, the smaller probability of organizational failure. \\
\hline & & & Manager & 1 & Having managers who fear failure decreases the probability of organizational failure. \\
\hline \multirow{3}{*}{17} & \multirow{3}{*}{$\begin{array}{l}\text { Gémar Moniche } \\
\text { \& Morale, } \\
\text { (2016). }\end{array}$} & \multirow{3}{*}{$\begin{array}{l}\text { Survival analysis of the Spanish } \\
\text { hotel industry. }\end{array}$} & $\begin{array}{l}\text { Location } \\
\text { (network) }\end{array}$ & 2 & Companies (hotel) being located near to an international airport decreases the probability of organizational failure. \\
\hline & & & Manager & 1 & Managers lacking skills increase the probability of organizational failure. \\
\hline & & & $\begin{array}{l}\text { Economic } \\
\text { conditions }\end{array}$ & 3 & Economic crises increase the probability of organizational failure. \\
\hline 18 & $\begin{array}{l}\text { Gok, Deshpande, } \\
\text { S., Deshpande, }\end{array}$ & & $\begin{array}{l}\text { Economic } \\
\text { conditions }\end{array}$ & 3 & Economic crises increase the probability of organizational failure. \\
\hline
\end{tabular}




\begin{tabular}{|c|c|c|c|c|c|}
\hline & \multirow{4}{*}{$\begin{array}{l}\text { A. P., \& Hunter, } \\
(2012)\end{array}$} & \multirow{4}{*}{$\begin{array}{l}\text { Comparing promoter and } \\
\text { employee attributions for the } \\
\text { causes of firms' failure: the case } \\
\text { of Indian petrochemical } \\
\text { company. }\end{array}$} & Manager & 1 & Managers with insufficient leadership and planning skills, increase the probability of organizational failure. \\
\hline & & & Competitors & 2 & The greater the presence of new competitors, the greater the probability of organizational failure. \\
\hline & & & $\begin{array}{l}\text { Government } \\
\text { policies }\end{array}$ & 3 & The more liberal the economy becomes the greater the probability of organizational failure. \\
\hline & & & $\begin{array}{l}\text { Supplier } \\
\text { relations }\end{array}$ & 2 & The higher the cost of raw materials the greater the probability of organizational failure. \\
\hline 19 & Hollow (2014) & $\begin{array}{c}\text { Strategic inertia, financial } \\
\text { fragility and organizational } \\
\text { failure: the case of the Birkbeck } \\
\text { Bank, } 1870-1911 .\end{array}$ & Manager & 1 & Managers lacking skills to adapt to external change increases the probability of organizational failure \\
\hline \multirow[b]{2}{*}{20} & \multirow[b]{2}{*}{ Kalnins (2016) } & \multirow{2}{*}{$\begin{array}{l}\text { Beyond Manhattan: localized } \\
\text { competition and organizational } \\
\text { failure in urban hotel markets } \\
\text { throughout the United States. } \\
2000-2014 \text {. } \\
\end{array}$} & Enterprise size & 2 & The bigger the company, the greater probability of organizational failure. \\
\hline & & & $\begin{array}{c}\text { Location } \\
\text { (network) }\end{array}$ & 2 & Companies being located near to competitors, increases the probability of organizational failure. \\
\hline \multirow[b]{2}{*}{21} & \multirow{2}{*}{$\begin{array}{c}\text { Laitinen \& } \\
\text { Lukason (2014) }\end{array}$} & \multirow{2}{*}{$\begin{array}{l}\text { Do firm failure processes differ } \\
\text { across countries: evidence from } \\
\text { Finland and Estonia. }\end{array}$} & Managers & 1 & Managers lacking in skills increases the probability of organizational failure. \\
\hline & & & $\begin{array}{l}\text { Economic } \\
\text { conditions }\end{array}$ & 3 & Economic crises increase the probability of failure to occur. \\
\hline 22 & Mackie (2012) & $\begin{array}{c}\text { Bearing 'the burden and heat of } \\
\text { the day': the experience failure in } \\
\text { Douglas \& Grant Ltd. }\end{array}$ & Manager & 1 & $\begin{array}{l}\text { Very optimistic managers, with a lack of skills and a reluctant to share the knowledge, will increase the probability } \\
\text { of organizational failure. }\end{array}$ \\
\hline \multirow{5}{*}{23} & \multirow{5}{*}{$\begin{array}{l}\text { Madrid-Guijarro, } \\
\text { García-Pérez-de- } \\
\text { Lema \& Van } \\
\text { Auken, (2011). }\end{array}$} & \multirow{5}{*}{$\begin{array}{c}\text { An analysis of non-financial } \\
\text { factors associated with financial } \\
\text { distress. }\end{array}$} & $\begin{array}{l}\text { Customer } \\
\text { relations }\end{array}$ & 2 & The greater the bargain power of customer's buyers, the greater the probability of organizational failure. \\
\hline & & & Competitors & 2 & The greater the rivalry among firms, the greater the probability of organizational failure. \\
\hline & & & $\begin{array}{l}\text { Physical } \\
\text { resource }\end{array}$ & 2 & The greater the technological capacity of the firm, the lower the probability of organizational failure. \\
\hline & & & Institution & 3 & Presence of regulatory institutions decreases the probability of organizational failure. \\
\hline & & & $\begin{array}{c}\text { Government } \\
\text { policies }\end{array}$ & 3 & Insufficient government policies increase the probability of organizational failure. \\
\hline 24 & $\begin{array}{l}\text { Maté-Sánchez- } \\
\text { Val, López- } \\
\text { Hernandez \& } \\
\text { Fuentes, (2018) } \\
\end{array}$ & $\begin{array}{c}\text { Geographical factors and } \\
\text { business failure: an empirical } \\
\text { study from the Madrid } \\
\text { metropolitan area. }\end{array}$ & $\begin{array}{l}\text { Localization } \\
\text { (network) }\end{array}$ & 2 & $\begin{array}{l}\text { Companies located near universities or research centers have less probability of organizational failure. Companies } \\
\text { located near to others that have failed tend to have less probability of organizational failure. }\end{array}$ \\
\hline 25 & Nilsson (2016) & $\begin{array}{l}\text { The influence of related and } \\
\text { unrelated industry diversity on } \\
\text { retail firm failure. }\end{array}$ & $\begin{array}{l}\text { Location } \\
\text { (network) }\end{array}$ & 2 & $\begin{array}{l}\text { Companies located near to competitors increases the probability of organizational failure. Companies located near to } \\
\text { those of another industry, decreasse the probability of organizational failure }\end{array}$ \\
\hline \multirow[b]{2}{*}{26} & \multirow{2}{*}{$\begin{array}{l}\text { Nummela, } \\
\text { Saarenketo, \& } \\
\text { Loane, (2016) }\end{array}$} & \multirow{2}{*}{$\begin{array}{l}\text { The dynamics of failure in } \\
\text { international new ventures: a } \\
\text { case study of Finnish and Irish } \\
\text { software companies. }\end{array}$} & Manager & 1 & Managera are more confident, the greater the probability of organizational failure. \\
\hline & & & $\begin{array}{l}\text { Economic } \\
\text { conditions }\end{array}$ & 3 & Economic crises increase the probability of organizational failure \\
\hline \multirow[b]{2}{*}{27} & \multirow{2}{*}{$\begin{array}{l}\text { Oertel, } \\
\text { Thommes, \& } \\
\text { Walgenbach, } \\
\text { (2016). } \\
\end{array}$} & \multirow[b]{2}{*}{$\begin{array}{c}\text { Organizational failure in the } \\
\text { aftermath of radical institutional } \\
\text { change. }\end{array}$} & Institution & 3 & Institutions can affect the organizational failure either positively or negatively. \\
\hline & & & Manager & 1 & Managers lacking skills to adapt to institutional changes increase the probability of organizational failure. \\
\hline
\end{tabular}




\begin{tabular}{|c|c|c|c|c|c|}
\hline \multirow{5}{*}{28} & \multirow{5}{*}{$\begin{array}{c}\text { Pardo \& } \\
\text { Alfonso (2017) }\end{array}$} & \multirow{5}{*}{$\begin{array}{l}\text { Applying 'attribution theory' } \\
\text { to determine the factors that } \\
\text { lead to the failure of } \\
\text { entrepreneurial ventures in } \\
\text { Colombia, }\end{array}$} & $\begin{array}{l}\text { Economic } \\
\text { conditions }\end{array}$ & 3 & $\begin{array}{l}\text { Economic crises increase the probability of organizational failure. Countries that face difficulty in accessing credit, } \\
\text { increase the probability of organizational failure. }\end{array}$ \\
\hline & & & Manager & 1 & The greater the presence of "inept" managers, the greater the probability of organizational failure. \\
\hline & & & $\begin{array}{c}\text { Human } \\
\text { resources }\end{array}$ & 2 & $\begin{array}{l}\text { Inadequate sales and promotion techniques, lead to a greater probability of organizational failure. The greater the } \\
\text { lack of training, the greater the probability that organizational failure will occur. }\end{array}$ \\
\hline & & & $\begin{array}{l}\text { Supplier } \\
\text { relations }\end{array}$ & 2 & Existence of suppliers' contractual problems, increases the likelihood of organizational failure. \\
\hline & & & Competitors & 2 & The greater the presence of new competitors, the greater the probability of organizational failure. \\
\hline \multirow{3}{*}{29} & \multirow{3}{*}{$\begin{array}{l}\text { Petković, Jäger } \\
\& \text { Sašić, (2016) }\end{array}$} & \multirow{3}{*}{$\begin{array}{l}\text { Challenges of small and medium } \\
\text { size companies at early stage of } \\
\text { development: insights from } \\
\text { Bosnia and Herzegovina. }\end{array}$} & Institution & 3 & Complex institutions increase the probability of organizational failure \\
\hline & & & $\begin{array}{c}\text { Human } \\
\text { resources }\end{array}$ & 2 & Employees who are lacking the skills to recover debt, increase the probability of organizational failure. \\
\hline & & & $\begin{array}{l}\text { Economic } \\
\text { conditions }\end{array}$ & 3 & $\begin{array}{l}\text { The higher the local tax, the greater the probability of organizational failure. Economic crises increase the } \\
\text { probability of organizational failure. The greater the difficulty in accessing credit, the greater the probability of } \\
\text { organizational failure. }\end{array}$ \\
\hline \multirow{4}{*}{30} & \multirow{4}{*}{$\begin{array}{l}\text { Priego, Lizano \& } \\
\text { Madrid, (2014) }\end{array}$} & \multirow{4}{*}{$\begin{array}{l}\text { Business failure: incidence of } \\
\text { stakeholders' behavior. }\end{array}$} & $\begin{array}{c}\text { Shareholders } \\
\text { relation }\end{array}$ & 2 & The better the relationships with shareholders the lower the probability of organizational failure. \\
\hline & & & $\begin{array}{l}\text { Human } \\
\text { resource }\end{array}$ & 2 & $\begin{array}{l}\text { The more that employees are not motivated to generate value for the company, the greater the probability of } \\
\text { organizational failure. }\end{array}$ \\
\hline & & & $\begin{array}{l}\text { Economic } \\
\text { conditions }\end{array}$ & 3 & $\begin{array}{l}\text { The more likely it is in the country for it to be difficult access to credit, the greater the probability of organizational } \\
\text { failure. }\end{array}$ \\
\hline & & & $\begin{array}{l}\text { Supplier } \\
\text { relation }\end{array}$ & 1 & The higher the cost of raw materials increases the probability of organizational failure. \\
\hline 31 & $\begin{array}{l}\text { Purves, Niblock } \\
\& \text { Sloan, (2016) } \\
\end{array}$ & $\begin{array}{l}\text { Are organizations destined to } \\
\text { fail? }\end{array}$ & Manager & 1 & $\begin{array}{l}\text { The more likely the presence of managers with few qualifications and experience, the greater the probability that } \\
\text { organizational failure will occur. }\end{array}$ \\
\hline 32 & $\begin{array}{l}\text { Revilla, Pérez- } \\
\text { Luño \& Nieto, } \\
\quad \text { (2016) }\end{array}$ & $\begin{array}{c}\text { Does family involvement in } \\
\text { management reduce the risk of } \\
\text { business failure? The moderating } \\
\text { role of entrepreneurial } \\
\text { orientation. }\end{array}$ & $\begin{array}{l}\text { Management } \\
\text { structure }\end{array}$ & 1 & $\begin{array}{l}\text { Family-run businesses where family members' presence is high in the daily management of a company, decrease the } \\
\text { probability of organizational failure. }\end{array}$ \\
\hline \multirow{3}{*}{33} & \multirow{3}{*}{ Safley (2009) } & \multirow{3}{*}{$\begin{array}{l}\text { Business failure and civil scandal } \\
\text { in early modern Europe. }\end{array}$} & Competitors & 2 & New competitors increase the probability of organizational failure. \\
\hline & & & Manager & 1 & Managers lacking in skills increases the probability of organizational failure to occur. \\
\hline & & & $\begin{array}{l}\text { Physical } \\
\text { resources }\end{array}$ & 2 & Companies lacking in resources to fulfill their contracts, increase the probability of organizational failure. \\
\hline \multirow[b]{2}{*}{34} & \multirow{2}{*}{ Santiago (2015) } & \multirow{2}{*}{$\begin{array}{l}\text { Inertia as inhibiting } \\
\text { competitiveness in Philippine } \\
\text { family business. }\end{array}$} & Manager & 1 & $\begin{array}{l}\text { Companies with authoritarian managers, have a greater probability of organizational failure. Managers without an } \\
\text { innovational focus, increase the probability of organizational failure. }\end{array}$ \\
\hline & & & Succession & 2 & Succession processes that are badly planned, increase the probability of organizational failure. \\
\hline 35 & $\begin{array}{c}\text { Van Scheers } \\
(2011)\end{array}$ & $\begin{array}{l}\text { SME's Marketing skills } \\
\text { challenges in South Africa. }\end{array}$ & $\begin{array}{c}\text { Human } \\
\text { resources }\end{array}$ & 2 & Companies whose salespeople have better sales skills, decrease the probability of organizational failure. \\
\hline \multirow{2}{*}{36} & \multirow{2}{*}{$\begin{array}{l}\text { Vivel-Bua, } \\
\text { Lado-Sestayo \& }\end{array}$} & \multirow{2}{*}{$\begin{array}{l}\text { Impact of location on the } \\
\text { probability of default in the }\end{array}$} & $\begin{array}{l}\text { Financial } \\
\text { resources }\end{array}$ & 2 & $\begin{array}{l}\text { The lower the profitability, the economic and financial balance sheet and the liquidity of the company, the greater } \\
\text { the probability of organizational failure. }\end{array}$ \\
\hline & & & Enterprise age & 2 & The younger the company, the greater the probability of organizational failure \\
\hline
\end{tabular}




\begin{tabular}{|c|c|c|c|c|c|}
\hline & $\begin{array}{l}\text { Otero-González, } \\
\text { (2016) }\end{array}$ & $\begin{array}{l}\text { Spanish lodging industry: a study } \\
\text { of MSMEs. }\end{array}$ & Enterprise size & 2 & The smaller the company, the greater probability of organizational failure. \\
\hline 37 & White (2016) & Small business bankruptcy. & Institution & 3 & The existence of good bankruptcy legislation decreases the probability of organizational failure. \\
\hline \multirow{3}{*}{38} & \multirow{3}{*}{ Williams (2016) } & \multirow{3}{*}{$\begin{array}{l}\text { Can neural networks predict } \\
\text { business failure? Evidence from } \\
\text { small high tech firms in the UK. }\end{array}$} & $\begin{array}{l}\text { Financial } \\
\text { resources }\end{array}$ & 2 & The lower the retained earnings, the greater the probability of organizational failure. \\
\hline & & & Enterprise size & 2 & The smaller the company, the greater the probability of organizational failure. \\
\hline & & & $\begin{array}{l}\text { Location } \\
\text { (network) }\end{array}$ & 2 & Localities with low access to human capital will lead to a greater probability of organizational failure. \\
\hline \multirow{2}{*}{39} & \multirow{2}{*}{$\begin{array}{l}\text { Wilson, Wright, } \\
\text { \& Altanlar, } \\
\text { (2014) }\end{array}$} & \multirow{2}{*}{$\begin{array}{l}\text { The survival of newly- } \\
\text { incorporated companies and } \\
\text { founding director characteristics. }\end{array}$} & Manager & 1 & $\begin{array}{l}\text { Experienced managers, with a great networking ability, and who have experienced insolvency in the past, decrease } \\
\text { the probability of organizational failure to occur. }\end{array}$ \\
\hline & & & $\begin{array}{l}\text { Human } \\
\text { resources }\end{array}$ & 2 & $\begin{array}{l}\text { The presence of female managers, a high number of local directors and a low level of managerial turnover, decrease } \\
\text { the probability of organizational failure }\end{array}$ \\
\hline \multirow{4}{*}{40} & \multirow{4}{*}{$\begin{array}{l}\text { Wollebaek } \\
\text { (2009) }\end{array}$} & \multirow{4}{*}{$\begin{array}{l}\text { Survival in local voluntary } \\
\text { associations. }\end{array}$} & Enterprise age & 2 & The younger the company, the greater probability of organizational failure. \\
\hline & & & Enterprise size & 2 & The smaller the company, the greater probability of organizational failure. \\
\hline & & & $\begin{array}{l}\text { Economic } \\
\text { conditions }\end{array}$ & 3 & The higher the target consumer population, the less probability of organizational failure \\
\hline & & & $\begin{array}{l}\text { Business } \\
\text { structure }\end{array}$ & 2 & The more centralized and formalized the company, the greater the probability of organizational failure. \\
\hline 41 & $\begin{array}{l}\text { Yonk, Harris, } \\
\text { Martin, \& } \\
\text { Anderson, } \\
\text { (2017) }\end{array}$ & $\begin{array}{l}\text { Exploring the case of The White } \\
\text { Moustache: Entrepreneurship } \\
\text { and regulatory capture on the } \\
\text { milk products industry. }\end{array}$ & Institution & 3 & Regulatory institutions can increase the probability of organizational failure \\
\hline
\end{tabular}


Figure 1: Flow chart outlining approach for article selection 
Macro Analytical Level

- Economic conditions:

. Economic crises (+)

. Unemployment (+)

Interest rate $(+)$

. Taxes $(+/-)$

- Formal institutions (+/-)

Government polices:

Public investment (-)

Liberalization of the economy $(+)$

- Competitors (+)

- Rumors (+)
Meso Analytical Level

Company age (-)

- Company size (-)

- Location (network) (-)

- Property structure:

. Diversity in board composition (-)

Hierarchy (-)

Clients relationship (-)

Suppliers relationship (-)

Shareholdres relationship (-)

- Financial resources (-)

Physical resources (-)

- Human resources (-)

-Succession process $(+)$

Organizational failure
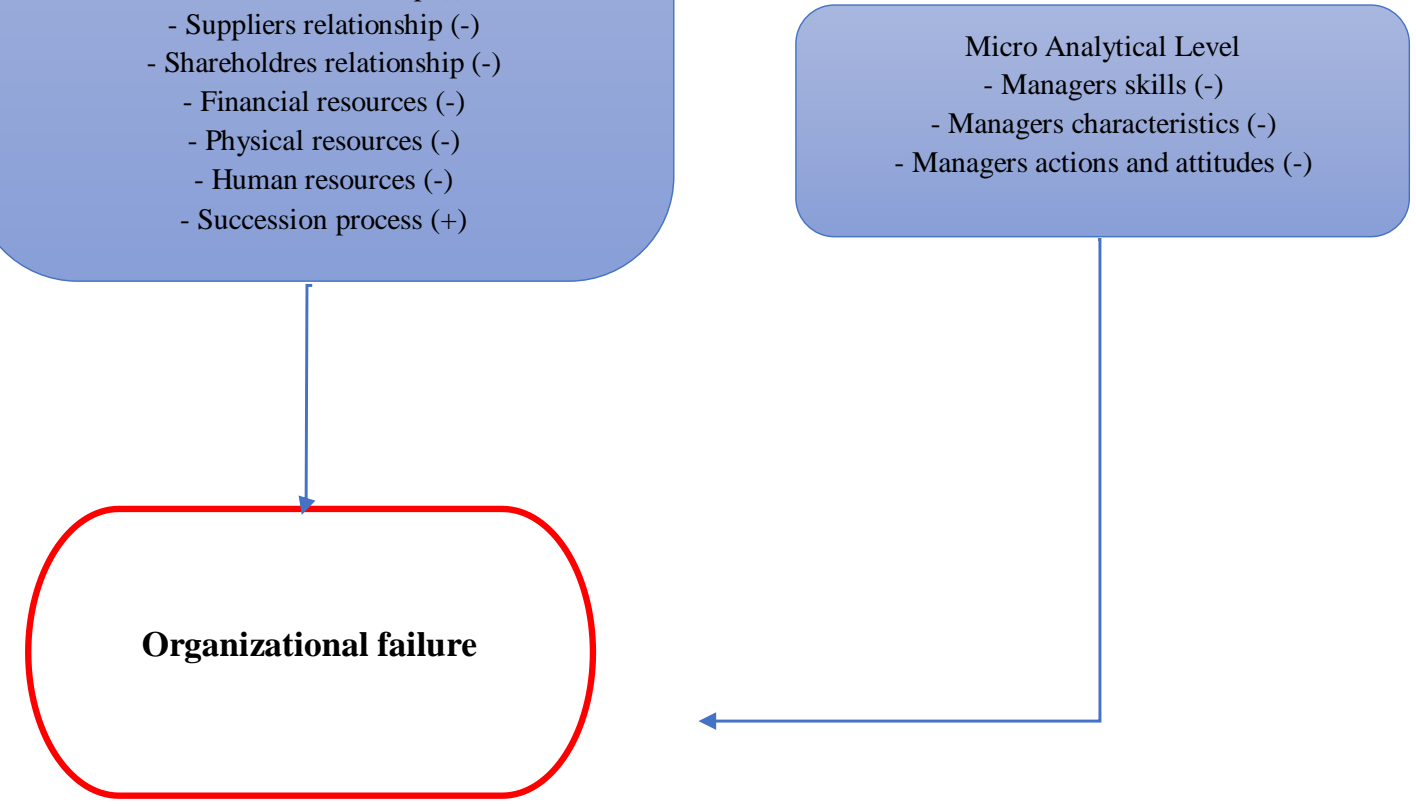

Micro Analytical Leve

Figure 2. Factors that influence the organizational failure 


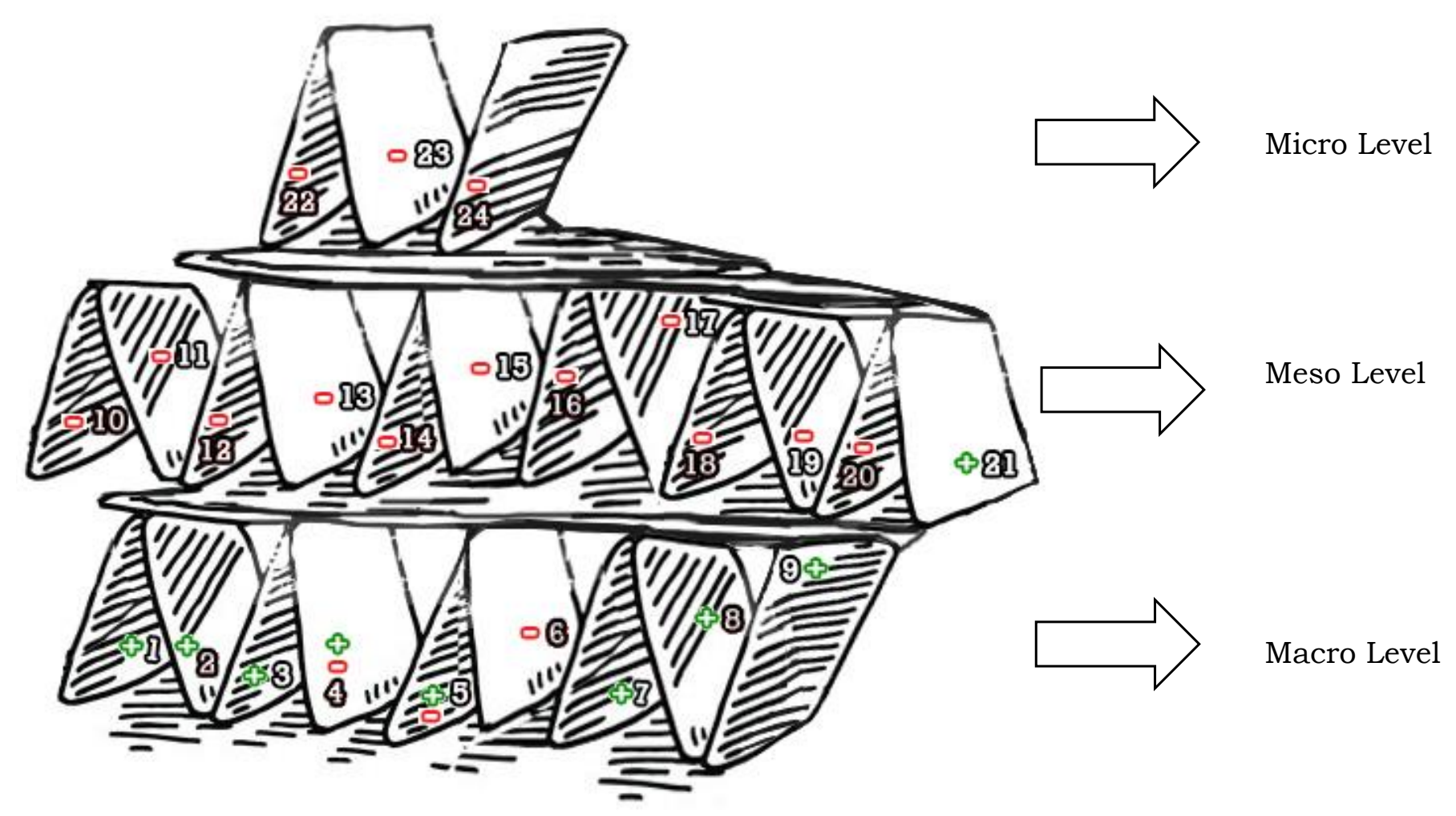

Figure 3: The "House of Cards Model" of organizational failure

6451 Economic crisis $\mathbf{2}$ Unemployment $\mathbf{3}$ Interest rates $\mathbf{4}$ Taxation systems $\mathbf{5}$ Formal institutions $\mathbf{6}$ Public investment $\mathbf{7}$ Liberalization of economy $\mathbf{8}$ Competitors $\mathbf{9}$ Rumors 10 Company age 11 Company size 12 Location (network) 13 Diversity in board composition 14 Hierarchy 15 Clients' relationship 16 Suppliers' relationship 